Joshua SHENKER

Chia S. $L A U$

Athanasios TSOLAKIS

Karl DEARN

Dale TURNER

Miroslaw L. WYSZYNSKI

\title{
The study of simulated biogas on combustion and emission characteristics in compression ignition engines
}

\begin{abstract}
New renewable fuels have been developed for diesel engines, contributing to the reduction of carbon emissions and to fuel security. However, the combustion characteristics of these fuels and emissions still remain unclear. A study to investigate diesel engine performance integrated with biogas and hydrogen has been carried out. Biogas is principally a mixture of methane $\left(\mathrm{CH}_{4}\right)$ and carbon dioxide $\left(\mathrm{CO}_{2}\right)$ along with other trace gases. In this study the simulated gaseous biogas $\left(60 \% \mathrm{CH}_{4}\right.$ and $40 \% \mathrm{CO}_{2}$ vol.) and hydrogen (2\% vol.) fuels were fed into the engine intake manifold and diesel fuel was injected into cylinder as a pilot ignition fuel. The effects of biogas and hydrogen showed reduced PM compared with diesel combustion. In addition, up to 39 and 33\% reduction in total particulate mass and smoke, respectively, was seen. However, there was a slight increase in particle number when gaseous fuel addition was used, where the particulate size distributions have moved towards the nucleation region thus benefitting the after-treatment systems. Reduced thermal efficiency was observed for the gaseous fuel addition.
\end{abstract}

Key words: biogas, hydrogen, combustion, emissions, thermal efficiency

\section{Wpływ biogazu na charakterystyki spalania i emisji silnika o zapłonie samoczynnym}

\begin{abstract}
Nowe odnawialne paliwa dla silników o zapłonie samoczynnym (ZS) przyczyniaja się do zmniejszenia emisji dwutlenku węgla oraz do poprawy bezpieczeństwa zaopatrzenia w paliwa. Jednakże charakterystyki spalania tych paliw oraz ich właściwości emisyjne nie sa wciąż w petni zbadane. W artykule przedstawiono wyniki badań osiagów silnika ZS zasilanego w układzie podwójnym: olejem napędowym oraz biogazem $i$ wodorem. Biogaz jest mieszanina głównie metanu $\left(\mathrm{CH}_{4}\right)$ $i$ dwutlenku węgla $\left(\mathrm{CO}_{2}\right)$ oraz śladowych ilości innych gazów. W przedstawionych badaniach stosowano symulowany (syntetyczny) biogaz, zawierajacy $60 \% \mathrm{CH}_{4}$ i 40\% $\mathrm{CO}_{2}$. Paliwa gazowe dostarczane byty do kolektora dolotowego silnika, a paliwo ciekte (olej napędowy) było wtryskiwane do cylindra jako dawka zapłonowa. Efektem zastosowania biogazu $i$ wodoru było obniżenie emisji cząstek statych w porównaniu ze spalaniem czystego oleju napędowego. Zaobserwowano obniżona masowa emisję cząstek stałych i zmniejszenie dymienia (odpowiednio o 39 i 33\%). Przy użyciu paliwa gazowego zaobserwowano także nieznaczne zmiany liczby cząstek stałych, przy czym rozkład wymiarowy czastek przesuną się w stronę obszaru nukleacyjnego, co jest korzystne z punktu widzenia sprawności układów oczyszczania spalin. Zastosowanie paliw gazowych spowodowało również zmniejszenie sprawności cieplnej silnika.
\end{abstract}

Słowa kluczowe: biogaz, wodór, spalanie, emisja, sprawność cieplna

\section{Introduction}

The requirements of reduced emissions, enforced by stringent legislation and concerns for global environmental degradation has driven the demand for alternative environmentally friendly fuels for internal combustion engines [1]. Growing demand for fossil fuels and anticipation of future depletion of worldwide petroleum reserves provide strong encouragement for research on alternative fuels [2]. Biogas is one gaseous fuel currently attaining considerable attention from researchers. Its production can originate from anaerobic fermentation of organic material such as animal manure waste, water and solid waste, with composition varying depending on its sources, but usually $50-70 \% \mathrm{CH}_{4}, 25-50 \%$ $\mathrm{CO}_{2}, 1-5 \% \mathrm{H}_{2}, 0.3-3 \% \mathrm{~N}_{2}$ and traces of $\mathrm{H}_{2} \mathrm{~S}$ [3].

\section{Wstęp}

Wymagania redukcji emisji, wynikające z uregulowań prawnych i obaw o globalną degradację środowiska, prowadzą do wzrostu popytu na alternatywne, ekologiczne paliwa dla silników spalinowych [1]. Wzrastające zapotrzebowanie na paliwa kopalne oraz przewidywane wyczerpanie się w przyszłości światowych rezerw ropy naftowej stymulują prowadzenie badań nad paliwami zastępczymi [2]. Biogazjest jednym z takich paliw, cieszącym się znacznym zainteresowaniem badaczy. Produkcja biogazu oparta być może na beztlenowej fermentacji surowców organicznych takich jak odpadowy nawóz zwierzęcy, ścieki i odpady stałe. Jego skład zmienia się zależnie od źródła surowców, lecz zwykle wynosi (objętościowo): $50-70 \% \mathrm{CH}_{4}, 25-50 \% \mathrm{CO}_{2}, 1-5 \% \mathrm{H}_{2}$, 0,3-3\% $\mathrm{N}_{2}$ oraz śladowe ilości $\mathrm{H}_{2} \mathrm{~S}[3]$. 
Biogas as a fuel has considerably lower energy density on a volume basis (compared with methane or natural gas) on account of its high $\mathrm{CO}_{2}$ content. The large quantity of $\mathrm{CO}_{2}$ present in biogas reduces the overall calorific value, flame velocity and flammability range compared with natural gas. Published results have shown that the in-cylinder peak pressure and maximum power decrease due to the presence of $\mathrm{CO}_{2}$ in biogas [4]. Biogas with content more than $45 \%$ of $\mathrm{CO}_{2}$ can cause irregular running of engines and produces poor emissions [5]. Using this as a foundation, the present study utilised biogas containing $40 \%$ by volume $\mathrm{CO}_{2}$, on account for it being practically encountered in biogas.

Many experimental studies using various gaseous fuels/ sources such as natural gas, biogas, landfill and sewage gas reveal that the main constituent contributing to the heating value of the fuel is methane. Thus methane number could be used to classify various gaseous fuels in a similar way to the octane and cetane number used for gasoline and diesel engines respectively $[6,7]$. Gaseous fuel such as biogas is known to have high resistance to knock when used as a fuel in internal combustion engines [1]. It is therefore suitable for high compression ratio engines with the possibility of improvements to engine efficiency.

Presently, $\mathrm{H}_{2}$ has been characterised as a promising alternative fuel for internal combustion engines, showing promising capabilities in emission control and engine performance. Its use in internal combustion engines has been known to improve the fuel economy, combustion stability, extend the engine tolerance of EGR and reduce exhaust gas emissions [8]. Numerous researchers have previously studied the effect of adding a small quantity of $\mathrm{H}_{2}$ to liquid fuels to improve their combustion properties. The property of $\mathrm{H}_{2}$, specifically its wide range of flammability makes it an ideal gaseous fuel to combine with liquid fuels, thereby improving combustion properties. Adding around 2\%vol. of $\mathrm{H}_{2}$ into diesel engines can effectively assist the reduction of $\mathrm{NO}_{x}$ emission without significantly affecting performance and drivability [9].

Research conducted on biogas indicates that emissions are reduced and the lean-burn characteristics are improved, and that HCCI (CAI) combustion of biogas is made possible when hydrogen produced on-line by fuel reforming with exhaust gas is added as part of the mixture $[10,11]$. But there have been few explanations about biogas and $\mathrm{H}_{2}$ mixture in case of particulate matter and its smoke emission characteristics. In the present work, the simulated biogas, $60 \%$ $\mathrm{CH}_{4}$ and $40 \% \mathrm{CO}_{2}$, with additional $\mathrm{H}_{2}$ were inducted into the engine and the combustion, particulate matter, smoke, emission and performance characteristics were investigated. The study compared the results of such characteristics whit the engine running solely on diesel fuel, diesel and biogas mixture and diesel, biogas and $\mathrm{H}_{2}$ mixture.

\section{Experimental setup}

To perform the experiment, minor modifications to the test rig were performed, primarily to allow for duel fuelling. Today's common dual-fuel engines usually have a mixed gaseous fuel-air cylinder either through direct mixing in the
Biogaz jako paliwo ma znacznie niższą objętościową gęstość energetyczną (w porównaniu z metanem czy gazem ziemnym) z powodu dużej zawartości $\mathrm{CO}_{2}$. Wysoka zawartość $\mathrm{CO}_{2}$ w biogazie obniża jego wartość opałową, prędkość rozprzestrzeniania się płomienia i zakres palności w porównaniu z gazem ziemnym. Dane literaturowe wskazują, że maksymalne ciśnienie w cylindrze oraz moc maksymalna zmniejszają się właśnie z powodu obecności $\mathrm{CO}_{2} \mathrm{w}$ biogazie [4]. Biogaz o zawartości $\mathrm{CO}_{2}$ wyższej niż $45 \%$ może powodować nieregularną pracę silnika oraz prowadzi do pogorszenia czystości spalin [5]. Z tego względu w przedstawionych $\mathrm{w}$ artykule badaniach stosowano symulowany (syntetyczny) biogaz, zawierający $40 \%$ obj. $\mathrm{CO}_{2}$, czyli w takiej ilości jaką spotka się w praktyce.

Wiele badań eksperymentalnych z zastosowaniem rozmaitych paliw gazowych takich jak gaz ziemny, biogaz, gaz ze składowisk śmieci oraz gaz z oczyszczalni ścieków potwierdza że głównym gazem odpowiedzialnym za wartość opałową paliwa jest metan. Tak więc liczba metanowa może być stosowana do oceny różnych paliw gazowych, w podobny sposób jak liczba oktanowa i cetanowa są stosowane odpowiednio do benzyn i olejów napędowych [6, 7]. Paliwa gazowe takie jak biogaz używane w silnikach spalinowych znane są z wysokiej odporności na spalanie stukowe [1]. Są one wobec tego odpowiednie dla silników o wysokim stopniu sprężania, co daje możliwość podwyższenia sprawności silnika.

Od pewnego czasu wodór $\mathrm{H}_{2}$ jest opisywany jako obiecujące paliwo alternatywne dla silników spalinowych, wykazujące potencjalne możliwości obniżenia emisji oraz uzyskania wysokich osiągów silnika. Zastosowanie wodoru w silnikach spalinowych wykazywało zmniejszenie zużycia paliwa, poprawę stabilności spalania, rozszerzenie tolerancji na recyrkulacje spalin (exhaust gas recirculation EGR) oraz zmniejszenie emisji spalin [8]. Wiele prac poświęcono badaniom wpływu dodawania małej ilości $\mathrm{H}_{2}$ do paliw płynnych na przebieg ich spalania. Właściwości $\mathrm{H}_{2}$, a szczególnie jego szeroki zakres palności czyni go idealnym paliwem gazowym do łączenia z paliwami płynnymi, w celu poprawy ich własności palnych. Wprowadzenie około $2 \%$ $\mathrm{H}_{2}$ w przypadku silników ZS, może skutecznie wspomagać zmniejszanie emisji $\mathrm{NO}_{\mathrm{x}}$ bez znacznego wpływu na osiągi i właściwości napędowe silnika [9].

Badania prowadzone z użyciem biogazu wykazują zmniejszenie emisji i poprawę wskaźników spalania ubogiej mieszanki, a także możliwość spalania biogazu w technologii zapłonu samoczynnego mieszanki jednorodnej HCCI (CAI), w sytuacji gdy jako część mieszanki dodawany jest wodór wytwarzany na bieżąco (on-line) poprzez reforming paliwa w kontakcie w gazami spalinowymi $[10,11]$. Istnieje jednak niewiele prac dotyczących charakterystyk emisji cząstek stałych i dymienia przy zastosowaniu mieszanek biogazu i $\mathrm{H}_{2}$. W badaniach opisanych w niniejszym artykule stosowano symulowany biogaz zawierający $\mathrm{CH}_{4}$ i CO, z dodatkiem $\mathrm{H}_{2}$. Stosując te paliwa badano charakterystyki spalania, emisję cząstek stałych, dymienie i osiągi silnika. Otrzymane wyniki porównano z 
intake manifold or direct injection into cylinder. The resultant mixture inside the cylinder at the end of compression stroke is ignited by a small amount of pilot liquid fuel. In respect to this study the gaseous fuels (biogas and $\mathrm{H}_{2}$ ) acted as a supplement for the conventional diesel engine.

The experiment was carried out on a Lister-Petter TR1 engine, air-cooled, single-cylinder direct injection diesel engine. An electric DC dynamometer with a load cell was coupled to the engine and used to motor and load the engine. Figure 1 shows the experimental layout highlighting the feed of the gaseous fuel into the air intake and the sampling locations.

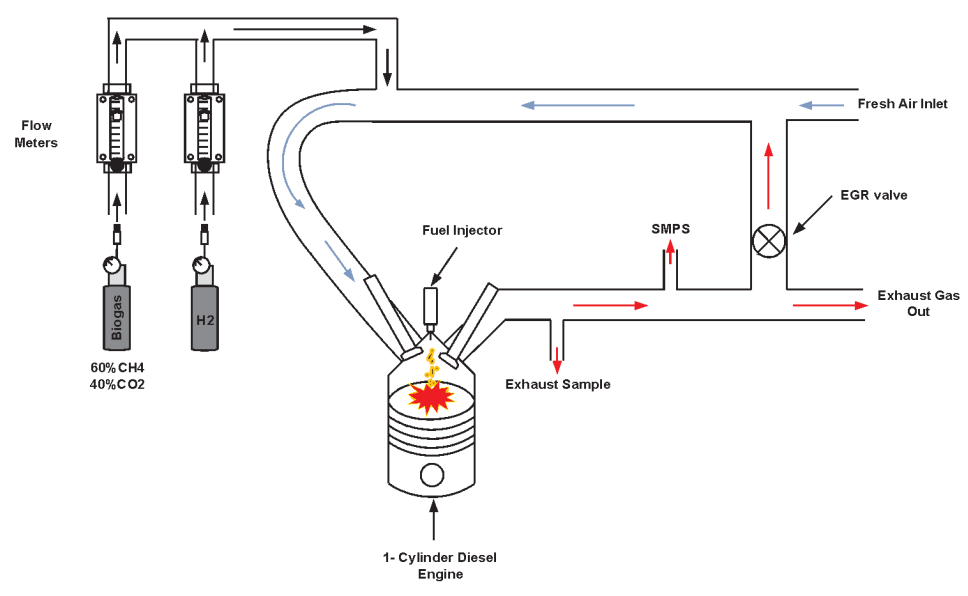

Fig. 1. Schematic diagram of experimental setup Rys. 1. Schemat układu badawczego

Flow meters - przeptywomierze, Fresh air inlet - wlot świeżego powietrza, EGR valve zawór recyrkulacji spalin, Fuel injector - wtryskiwacz paliwa, SMPS - Scanning Mobility Particle Sizer - Analizator wykorzystujacy skaningowy rozkład wielkości czastek stałych, Exhaust gas out - wylot gazów spalinowych, Exhaust sample - próbka spalin, Cylinder Diesel engine - jednocylindrowy silnik ZS

A Horiba MEXA 7100DEGR emissions analyser was used for the measurements of carbon dioxide and, carbon monoxide by Non-Disperse Infrared (NDIR), oxygen by electrochemical method, nitrogen oxide $\left(\mathrm{NO}_{\mathrm{x}}=\mathrm{NO}+\mathrm{NO}_{2}\right)$ and nitrogen monoxide (NO) by chemiluminescence detection (CLD), and hydrocarbons (HC) by flame ionization detector (FID).

An AVL 415S Smoke Meter was used for measuring the smoke in the exhaust gas of the engine. The result of the measurement was displayed as a filter smoke number (FSN) conforming to ISO 10054.

An SMPS (Scanning Mobility Particle Sizer) unit was used to measure the size distribution of fine particles by separating particles based on their electrical-mobility. The in-cylinder pressure was recorded by using a Kistler 6125B pressure transducer ( $1 \%$ measurement accuracy) mounted flush at the cylinder head and connected via a Kistler 5011 charge amplifier to a National Instruments data acquisition board. A digital shaft encoder was used to measure the crankshaft position. Data acquisition and combustion analysis were carried out using in-house developed LabVIEW- podobnymi wynikami uzyskanymi przy zasilaniu wyłącznie olejem napędowym.

\section{Stanowisko badawcze}

Dla przeprowadzenia opisanych w artykule badań, niezbędne było wykonanie pewnych zmian w typowym silnikowym stanowisku badawczym. Zmiany dotyczyły głównie zastosowania podwójnego zasilania paliwem. Współczesne silniki pracujące $\mathrm{z}$ podwójnym zasilaniem paliwem zwykle mają w cylindrze mieszankę powietrza i paliwa gazowego wytwarzaną albo przez bezpośrednie mieszanie w kolektorze wlotowym albo przez bezpośredni wtrysk do cylindra.

Tak wytworzona mieszanka jest zapalana w cylindrze pod koniec suwu sprężania przez niewielką ilość wtryskiwanego paliwa płynnego.

Badania przeprowadzono na jednocylindrowym silniku ZS typu Lister-Petter TR1, $\mathrm{z}$ bezpośrednim wtryskiem paliwa, chłodzonym powietrzem. Z silnikiem połączony był hamulec, elektryczny generator prądu stałego z miernikiem obciążenia, który napędzał silnik lub odbierał z niego moc. Na rysunku 1 przedstawiono stanowisko badawcze, ze szczególnym uwzględnieniem doprowadzania paliwa gazowego do wlotu powietrza oraz lokalizacji punktów pobierania próbek.

W badaniach używano analizatora spalin marki HORIBA MEXA 7100DEGR, który był stosowany do pomiarów dwutlenku węgla i tlenku węgla metodą niedyspersyjnej absorpcji podczerwieni (NDIR), tlenu metodą elektrochemiczną, tlenków azotu $\left(\mathrm{NO}_{\mathrm{x}}=\mathrm{NO}+\mathrm{NO}_{2}\right)$ oraz tlenku azotu (NO) metodą chemiluminescencyjną (CLD) oraz niespalonych węglowodorów (HC) metodą płomieniowo-jonizacyjną (FID).

Dymomierz AVL 415S był stosowany do pomiaru zadymienia spalin. Wynik pomiaru podawany był jako stopień dymienia (Filter Smoke Number FSN) zgodnie z normą międzynarodową ISO 10054.

Analizator wykorzystujący skaningowy rozkład wielkości cząstek (Scanning Mobility Particle Sizer SMPS) był stosowany do pomiaru rozkładu wymiarowego cząstek stałych poprzez ich separację w oparciu o mobilność w polu elektrycznym. Ciśnienie w cylindrze mierzone było z zastosowaniem przetwornika ciśnienia Kistler 6125B (dokładność pomiaru 1\%) zamontowanego równo z wewnętrzną powierzchnią głowicy cylindra oraz wzmacniacza ładunku Kistler 5011 do karty pomiaru danych National Instruments. Do pomiaru położenia wału korbowego używany był cyfrowy przetwornik obrotowy. Pozyskiwanie danych i analiza spalania przeprowadzane były z zastosowaniem autorskiego oprogramowania stworzonego na platformie LabVIEW. Stanowisko badawcze zawierało również inne standardowe oprzyrządowanie takie jak: termopary do pomiaru temperatur oleju smarnego, powietrza na dolocie, w kolektorze doloto- 
based software. The test rig included other standard engine instrumentation, such as thermocouples to measure oil, air, inlet manifold and exhaust temperatures and pressure gauges mounted at relevant points [12].

The engine speed and load used were $1500 \mathrm{rpm}$ and 4 bar IMEP (approximately $60 \%$ of the maximum load). The liquid fuel used was ultra low sulphur diesel (ULSD) provided by Shell Global Solutions UK with sulphur and aromatic hydrocarbon contents of $38 \mathrm{mg} / \mathrm{kg}$ and $23.7 \mathrm{wt} \%$ correspondingly. A standard fuel injection timing (22 CAD) of the engine was employed. For the gaseous fuels, a bottled biogas gaseous fuel with composition of $60 \% \mathrm{CH}_{4}$ and $40 \% \mathrm{CO}_{2}$ by volume and a bottled hydrogen gaseous fuel were used which were fed into the engine through the intake manifold. The volume of biogas and $\mathrm{H}_{2}$ added to the engine was approximately $2 \%$ of the air intake. The injected gaseous fuels took part as supplement for liquid fuel, hence the engine was acting as a dual-fuel engine. The supplementary fuel (biogas and hydrogen) was mixed in advance before being injected into the combustion chamber. However in order to initiate combustion pilot liquid fuel was injected towards the end of compression stroke. Three conditions' were studied; firstly running the engine on diesel fuel, secondly feeding $2 \%$ vol. of biogas into the air intake and thirdly a mixture of $2 \%$ vol. biogas with $2 \%$ vol. $\mathrm{H}_{2}$.

\section{Results and discussion}

\subsection{Cylinder pressure and rate of heat release}

Figure 2 shows the in-cylinder pressure and the rate of heat release $(\mathrm{ROHR})$ recorded at engine speed and load of $1500 \mathrm{rpm}$ and 4 bar IMEP. The Figure reveals that in the case of diesel fuelling the majority of the fuel is burnt at the premixed combustion phase. Additionally, the dual fuelled engine conditions show decreases in the in-cylinder pressure at the compression phase compared to diesel fuelling only. The addition of $2 \%$ biogas resulted in the in-cylinder peak pressure decreasing, however with further addition of $2 \% \mathrm{H}_{2}$ the in-cylinder peak pressure increased. The in-cylinder peak pressure and overall combustion with gaseous fuels shifted to a later stage (expansion stroke) resulting in no adverse effect on the engine. The lower calorific value of biogas and air mixture resulted in a decrease in cylinder pressure, although the higher calorific value of $\mathrm{H}_{2}$ and air mixture resulted in an increase in in-cylinder pressure. In comparison to other investigations, similar results were observed showing $\mathrm{H} 2$ increasing the peak in-cylinder pressure in comparison to diesel fuel alone [13].

In the case of diesel operation the start of fuel evaporation could be identified from the pressure trace at -17 CAD, while with biogas addition, the start of diesel evaporation was advanced by $1 \mathrm{CAD}$, and with additional $\mathrm{H}_{2}$ supplied the start of diesel evaporation was advanced by 3 CAD. This is essentially due to the lower density of biogas and $\mathrm{H}_{2}$ compared to diesel fuel. However, the identified start of combustion was identical for all conditions (i.e. 9 CAD), resulting in an increased ignition delay for when biogas and $\mathrm{H}_{2}$ were added. A significant shortening wym i gazów wylotowych, oraz manometry zamontowane w odpowiednich lokalizacjach [14].

Table 1. Test engine specification

Tabela 1. Dane silnika badawczego

\begin{tabular}{|c|c|}
\hline Engine specification/parametry silnika & Data/dane \\
\hline Model & Lister-Petter TR1 \\
\hline Number of cylinders/liczba cylindrów & 1 \\
\hline $\begin{array}{l}\text { Bore/stroke/ } \\
\text { średnica cylindra/skok }\end{array}$ & $98.4 \mathrm{~mm} / 101.6 \mathrm{~mm}$ \\
\hline Connecting rod length/dlugossć korbowodu & $165 \mathrm{~mm}$ \\
\hline Displacement volume/objętość skokowa & $773 \mathrm{~cm}^{3}$ \\
\hline $\begin{array}{l}\text { Compression ratio/stopień sprężania } \\
\text { (geometryczny) }\end{array}$ & 15.45 \\
\hline Rated power/moc nominalna $[\mathrm{kW}]$ & 8.6 at $2500 \mathrm{rpm}$ \\
\hline $\begin{array}{l}\text { Peak torque/maks. moment obrotowy } \\
{[\mathrm{N} \cdot \mathrm{m}]}\end{array}$ & 39.2 at $1800 \mathrm{rpm}$ \\
\hline Injection system/układ wtryskowy & $\begin{array}{l}\text { Three hole direct injec- } \\
\text { tion/wtrysk bezpośredni, } \\
\text { wtryskiwacz trójotwor- } \\
\text { kowy }\end{array}$ \\
\hline Engine piston/ttok silnika & $\begin{array}{c}\text { Bowl-in-piston/komora } \\
\text { kulista } w \text { ttoku }\end{array}$ \\
\hline
\end{tabular}

W czasie pomiarów prędkość i obciążenie silnika wynosiły odpowiednio $1500 \mathrm{obr} / \mathrm{min}$ oraz 4 bar IMEP (średnie ciśnienie indykowane) - co stanowiło około $60 \%$ obciążenia maksymalnego. Paliwem ciekłym był olej napędowy ultra-niskosiarkowy (ULSD), o zawartości siarki i węglowodorów aromatycznych odpowiednio $38 \mathrm{mg} / \mathrm{kg}$ oraz 23,7\% (masowo). Stosowano standardowy dla tego silnika kąt wyprzedzenia wtrysku (22o przed GMP). Jako paliwa gazowego używano gotowej mieszanki $60 \% \mathrm{CH}_{4}$ i $40 \% \mathrm{CO}_{2}$ (objętościowo) oraz wodoru dostarczanych z butli; paliwa gazowe doprowadzane były do kolektora dolotowego silnika. Objętość biogazu i wodoru kierowane do silnika stanowiły około $2 \%$ objętości powietrza wlotowego.

Paliwa gazowe dostarczane do silnika brały udział w procesie spalania razem z paliwem ciekłym, tak więc silnik działał jako silnik o podwójnym zasilaniu. Paliwa dodatkowe (biogaz i wodór) mieszane były przed wlotem do komory spalania. Dla zainicjowania spalania do komory spalania wtryskiwane było pod koniec suwu sprężania paliwo płynne. Zbadano trzy warianty zasilania, w pierwszym wypadku zasilając silnik wyłącznie olejem napędowym, w drugim wypadku doprowadzając do kolektora dolotowego $2 \%$ obj. biogazu, w trzecim zaś doprowadzając mieszankę $2 \%$ obj. biogazu i $2 \%$ obj. $\mathrm{H}_{2}$.

\section{Wyniki badań i ich dyskusja}

\subsection{Ciśnienie w cylindrze i szybkość wywiązywania się ciepla}

Na rysunku 2 przedstawiono przebieg ciśnienia w cylindrze oraz szybkość wywiązywania się ciepła (ROHR) uzyskane przy prędkości silnika $1500 \mathrm{obr} / \mathrm{min}$ i obciążeniu 4 bar IMEP. Widoczne jest, że w przypadku zasilania samym olejem napędowym większość paliwa spala się w fazie 


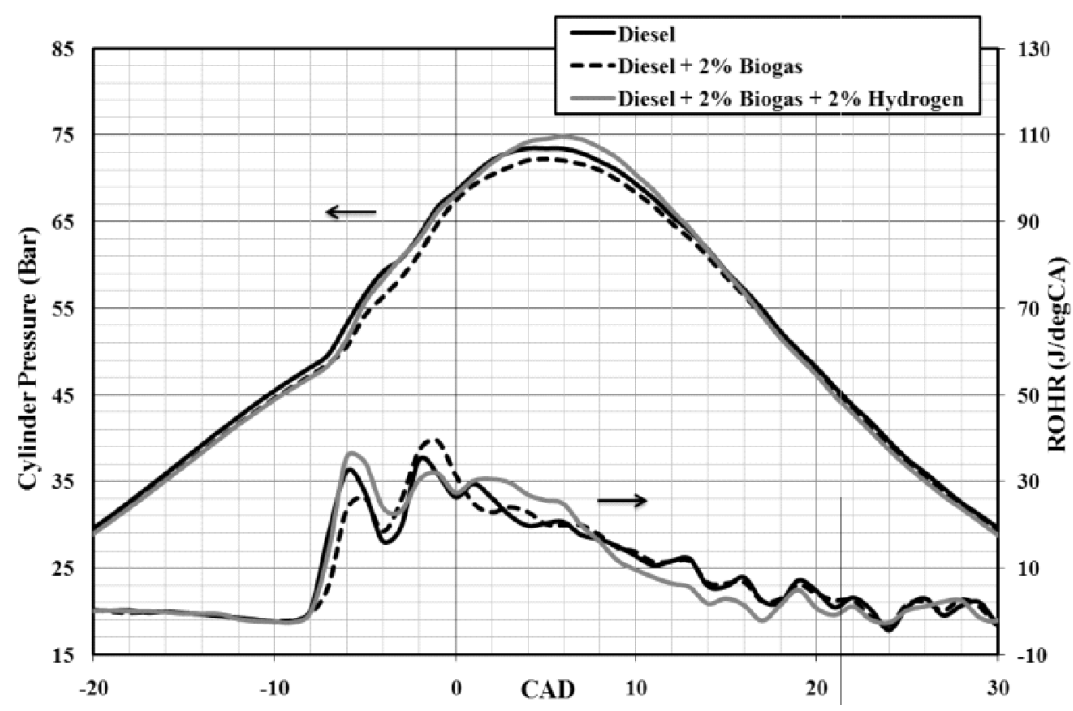

Fig. 2. In-cylinder pressure and rate of heat release (ROHR)

Rys. 2. Ciśnienie w cylindrze i prędkość wywiąywania się ciepła (ROHR) spalania kinetycznego. Dodatkowo przy podwójnym zasilaniu silnika, ciśnienie $\mathrm{w}$ cylindrze $\mathrm{w}$ fazie sprężania jest niższe niż w przypadku zasilania wyłącznie olejem napędowym. Dodatek 2\% biogazu spowodował spadek maksymalnego ciśnienia w cylindrze, jednakże dalszy dodatek $2 \% \mathrm{H}_{2}$ spowodował jego wzrost. Czas wystąpienia maksymalnego ciśnienia jak i ogólnie przebieg spalania z paliwami gazowymi przesunęły się do późniejszego okresu (suwu rozprężania), co nie spowodowało jednak ujemnych efektów dla silnika. Niższa wartość opałowa mieszanki biogazu i powietrza spowodowała spadek maksymalnego ciśnienia w cylindrze, natomiast wyższa wartość opałowa mieszanki $\mathrm{H}_{2}$ i powietrza spowodowała jego wzrost. $\mathrm{W}$ innych badaniach uzyskano podobne wyniki, tj. obecność $\mathrm{H}_{2}$ powodowała wzrost maksymalnego ciśnienia $\mathrm{w}$ cylindrze $\mathrm{w}$ porównaniu $\mathrm{z}$ zasilaniem

of combustion duration was observed with biogas and $\mathrm{H}_{2}$ fuel addition, as the end of combustion completed at an earlier CAD.

\subsection{Performance of dual-fuel engine operation}

Figure 3 below shows a slight decrease in engine indicated thermal efficiency as gaseous fuels are fed into the combustion chamber. This is due to diesel fuel and air replacement by gaseous fuel entering the combustion chamber creating incomplete combustion leading to higher specific fuel consumption. Moreover, though the calorific value of $\mathrm{H}_{2}$ is high and it has high flame velocity, the addition of another gaseous fuel into the cylinder lead to a maximum air replacement. It indicates that the engine performance is

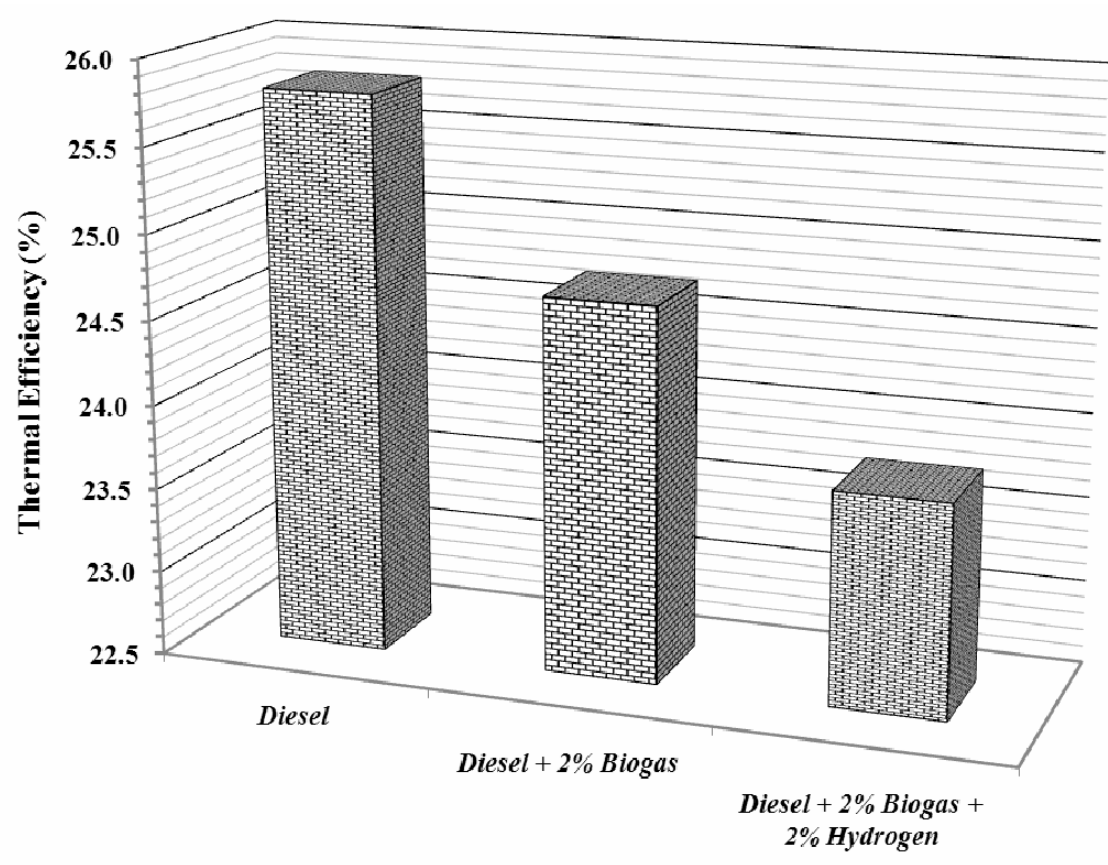

Fig. 3. Engine thermal efficiency (indicated) for the tested condition Rys. 3. Sprawność cieplna silnika (indykowana) dla badanego punktu pracy wyłącznie olejem napędowym [13].

W przypadku zasilania wyłącznie olejem napędowym początek odparowania paliwa mógł być zidentyfikowany z przebiegu ciśnienia w cylindrze przy -17 stopniach obrotu wału korbowego, podczas gdy przy dodatku biogazu początek odparowania oleju napędowego był przyśpieszony o $1^{\circ}$ OWK, a przy dodatkowym zasilaniu wodorem $\mathrm{H}_{2}$ początek odparowania oleju napędowego był przyspieszony o $3^{\circ}$ OWK. Jest to z zasadzie spowodowane niższą gęstością biogazu i $\mathrm{H}_{2}$ w porównaniu z olejem napędowym. Jednakże początek spalania był identyczny dla wszystkich warunków (tj. $\left.-9^{\circ} \mathrm{OWK}\right)$, dając w wyniku zwiększone opóźnienie spalania dla biogazu i $\mathrm{H}_{2}$. Zaobserwowano znaczne zmniejszenie czasu trwania spalania przy dodatku paliwa biogazowego i $\mathrm{H}_{2}$, ponieważ spalanie zakończyło się przy wcześniejszym kącie obrotu wału korbowego.

Rysunek 3 ukazuje niewielkie obniżenie indykowanej sprawności cieplnej silnika w przypadkach zasilania paliwami gazowymi. Jest to przypisywane wyparciu paliwa dieslowskiego i powietrza przez paliwo gazowe wpływające do komory spalania i co powoduje niekompletne spalanie prowadząc do zwiększenia znormalizowanego zużycia paliwa. Co więcej, chociaż wartość opałowa wodoru $\mathrm{H}_{2}$ jest wysoka i ma on wysoką prędkość płomienia, dodatek jeszcze innego paliwa gazowego do cylindra prowadzi do maksymalnego wyparcia

\subsection{Parametry pracy silnika przy podwójnym zasilaniu}




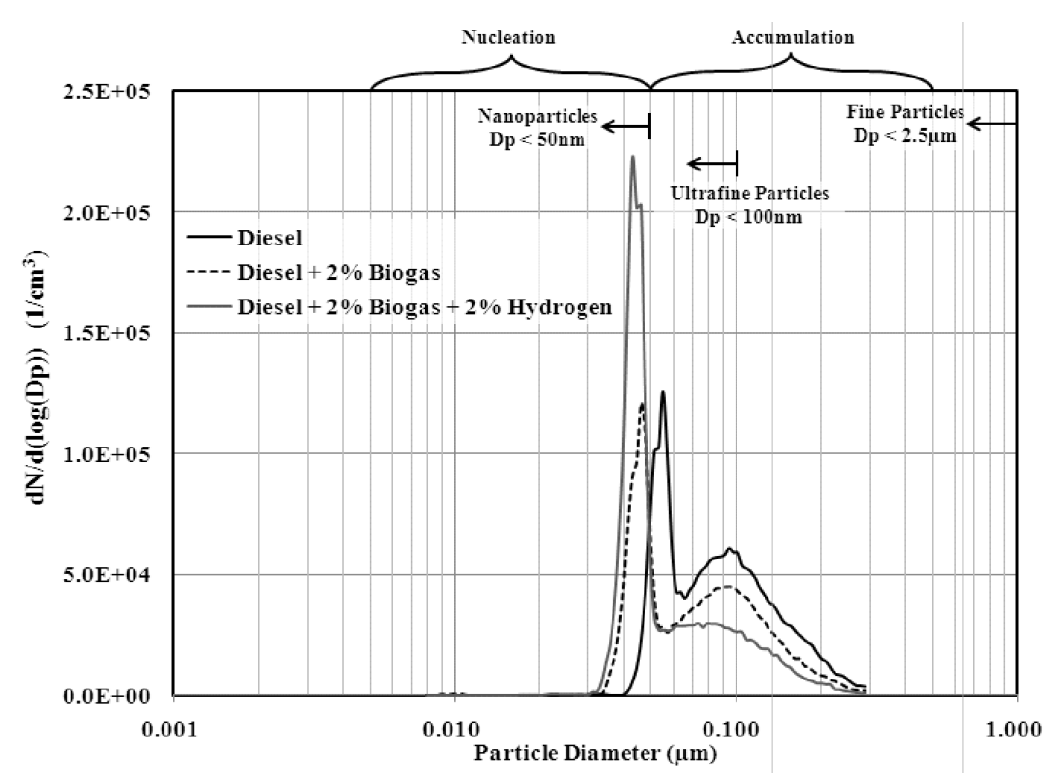

Fig. 4. Typical dual-fuel engine exhaust gas particle size distribution

Rys. 4. Typowy rozkład wielkości cząstek stałych w spalinach przy podwójnym zasilaniu (Nucleation - zakres nukleacyjny (zarodkowy), Nanoparticles - nanoczastki, Accumulation zakres akumulacyjny, Ultrafine particles - cząstki ultradrobne, Fine paricles - czastki drobne)

highly affected by the quantity and quality of the gas entering the combustion chamber. Deterioration in thermal efficiency in dual-fuel mode can be explained as a result of the different patterns of heat release with different modes of fuelling.

\subsection{Particulate matter}

Particle size distribution of particulate matter from the tested engine operating condition showed the typical bimodal character. The diameter of the particles becomes smaller as the curve shifts towards the nucleation region. When the engine is running solely on diesel fuel, most of the particles are distributed within the accumulation region; hence majority of the particles are ultrafine, however those from a dual-fuel mode mainly consist of nanoparticles. The results illustrated in Fig. 4 are similar to a previous study, where for the shape and number size distribution of the collected PM on filters showed that dual fuel PM were smaller and rounder than diesel PM [14].

For mass distribution the majority of the particulates (i.e. the particulate mass) are found in the accumulation mode. In number distributions, on the other hand, most particles are found in the nucleation mode. In other words, diesel particulate matter is composed of numerous small particles holding very little mass, mixed with relatively few larger particles which contain most of the total mass [14]. For biogas and $\mathrm{H}_{2}$ addition in Fig. 4, it can be seen that majority of the ultrafine particles have reduced and those nanoparticles in the nucleation region have increased, hence resulting in lower total PM mass as illustrated in Figure 5. In this study up to a 39\% reduction in total particulate mass was seen.

Based on the result of this work it revealed that the small particulate size is more advantageous for after-treatment systems due to the reduction in the powietrza. Wskazuje to że osiągi silnika są pod silnym wpływem ilości i jakości gazu wprowadzanego do komory spalania. Spadek sprawności cieplnej w reżimie dwupaliwowym widziany jest jako wynik bardzo różnych przebiegów wyzwalania ciepła przy różnych reżimach zasilania paliwem.

\subsection{Emisja cząstek stałych}

Rozkład wymiarowy cząstek stałych emitowanych przy badanych stanach pracy silnika wykazywał typowy charakter dwumodalny. Średnice cząstek stają się mniejsze gdy krzywa przesuwa się w stronę strefy nukleacyjnej. Gdy silnik pracuje wyłącznie na oleju napędowym, większość cząstek mieści się w zakresie akumulacyjnym, tak więc większość cząstek to cząstki ultradrobne, natomiast cząstki emitowane podczas pracy dwupaliwowej składają się głównie z nanocząstek. Wyniki przedstawione na rysunku 4 są podobne do wyników wcześniejszych badań kształtu i rozkładu ilościowego cząstek zebranych na filtrach, które wykazały że cząstki emitowane przy pracy dwupaliwowej są mniejsze i bardziej okrągłe niż cząstki emitowane przy zasilaniu wyłącznie olejem napędowym [14].

Biorąc pod uwagę rozkład masowy, większość cząstek (tj. większość masy cząstek stałych) znajduje się w zakresie akumulacyjnym. Z kolei dla rozkładu liczbowego większość cząstek znajduje się w zakresie nukleacyjnym (zarodkowym). Innymi słowy cząstki stałe emitowane z silnika składają się z dużej ilości małych cząstek niosących bardzo małą masę, zmieszanych ze stosunkowo niewielką ilością większych cząstek, które reprezentują większość całkowitej masy [14]. Przy dodatku biogazu i $\mathrm{H}_{2}$, jak to widać na rysunku 4, ilość cząstek ultradrobnych zmalała, a ilość nanocząstek w zakresie nukleacyjnym zwiększyła się, co prowadzi do niż-

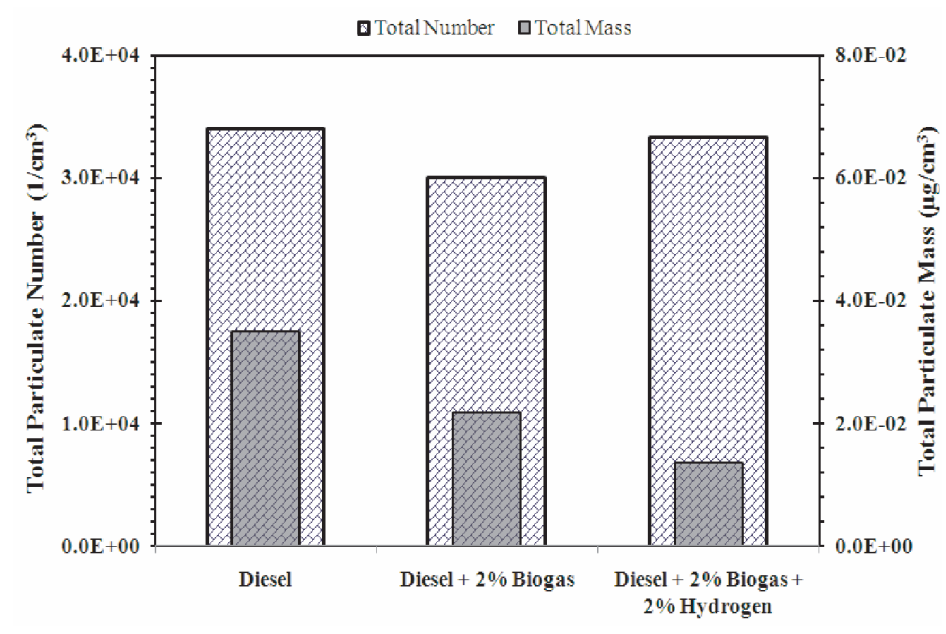

Fig. 5. Engine exhaust gas particle number and size distribution Rys. 5. Liczba i rozklad wymiarowy czastek statych $w$ spalinach (Total particulate number - calkowita liczba czastek, Total particulate mass calkowita masa cząstek) 


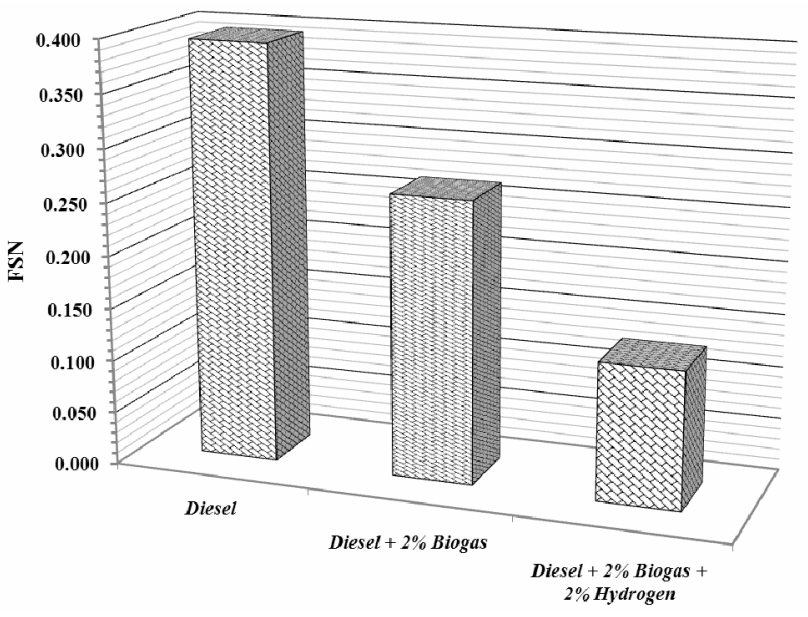

Fig. 6. Smoke number of engine exhaust gas Rys. 6. Wyniki pomiarów stopnia dymienia (FSN)

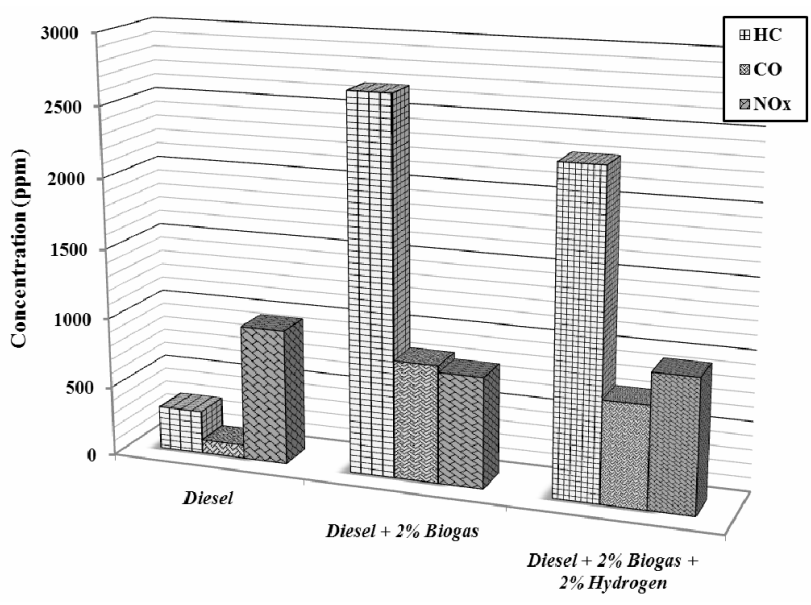

Fig. 7. Emission concentration of tested engine exhaust gas Rys. 7. Stężenia składników toksycznych w spalinach

catalyst deactivation. Particulate Matter consisting mainly of volatile organic materials (i.e. low diameter) is easier to oxidize over the catalyst, while there is no noticeable difference in the catalyst performance at the different engine operating conditions [15]. Moreover earlier studies using Johnson Matthey DOC technology, revealed that the converter can significantly modify PM size and composition by effectively removing organic carbon, such as SOF (soluble organic fraction), but has almost no effect on elementary carbon (soot) [16].

\subsection{Smoke Characteristics}

Figure 6 shows that there is a significant reduction in smoke opacity with biogas and $\mathrm{H}_{2}$ addition compared to diesel fuel only. The improvements reach $33 \%$ and $67 \%$ with biogas and $\mathrm{H}_{2}$ addition respectively. The reduction of smoke opacity in gaseous fuels addition was due to an increased premixed combustion in dual-fuel mode (Fig. 2). This premixed combustion leads to an increase in the amount of fuel-air mixture and hence increases the oxygen content of blended fuel. This suggests that smoke reduction can be szej całkowitej masy cząstek stałych (rys. 5). W opisanych w niniejszej pracy badaniach zaobserwowano zmniejszenie całkowitej masy cząstek stałych nawet o $39 \%$.

W oparciu o wyniki przedstawionych tu badań można stwierdzić że mniejsze rozmiary cząstek stałych są bardziej korzystne dla układów oczyszczania spalin z powodu zmniejszenia dezaktywacji katalizatora. Cząstki stałe składające się głównie z lotnego materiału organicznego (tj. cząstki mniejsze) są łatwiejsze do utlenienia na katalizatorze, przy czym nie ma zauważalnej różnicy w działaniu katalizatora przy różnych warunkach pracy silnika [15]. Co więcej, wcześniejsze badania z zastosowaniem reaktora utleniającego (diesel oxidation catalyst - DOC) z firmy Johnson Matthey pokazały, że reaktor katalityczny może znacznie zmodyfikować rozmiary i skład cząstek stałych poprzez skuteczne usunięcie organicznych związków węgla (rozpuszczalna frakcja organiczna SOF), natomiast prawie nie ma wpływu na węgiel elementarny (sadzę) [16].

\subsection{Zadymienie spalin}

Wyniki przedstawione na rysunku 6 wskazują na znaczne zmniejszenie zadymienia (smoke opacity) przy dodawaniu biogazu i $\mathrm{H}_{2}$ w porównaniu z zasilaniem samym olejem napędowym. Poprawa ta osiąga 33\% przy dodatku biogazu i $67 \%$ przy dodatku $\mathrm{H}_{2}$. Zmniejszenie zadymienia spalin przy dodawaniu paliw gazowych było wynikiem zwiększonego spalania wstępnie zmieszanej mieszanki paliwowej przy podwójnym zasilaniu (rys. 2). To wstępne zmieszanie prowadzi to zwiększenia ilości mieszanki paliwowo-powietrznej i tym samym zwiększa zawartość tlenu w zmieszanym paliwie. Sugeruje to, że zmniejszenie zadymienia może być przypisane poprawie mieszania paliwa $z$ powietrzem poprzez zwiększenie spalania mieszanki jednorodnej.

\subsection{Emisja gazowych składników spalin}

Przeprowadzone badania wskazują, że dodatek paliwa gazowego powoduje wzrost stężenia niespalonych węglowodorów HC w spalinach (rys. 7). Zaobserwowano duży wzrost emisji HC przy $2 \%$ dodatku biogazu. Z kolei dalszy dodatek $2 \% \mathrm{H}_{2}$ powodował zmniejszenie stężenia węglowodorów HC, choć w dalszym ciągu pozostaje ono wyższe niż w przypadku zasilania samym olejem napędowym. Wyniki te można łączyć z niższą temperaturą ładunku i wartością opałową mieszanych paliw z czego wynika mniej intensywne spalanie, co z kolei pozwala niektórym cząstkom paliwa na uniknięcie spalenia [17].

Zmniejszenie gęstości paliwa powoduje zwiększenie emisji tlenku węgla CO $[1,18]$. W opisywanych badaniach gęstość mieszanki paliw zmniejszyła się z powodu niższej gęstości paliwa gazowego w porównaniu $\mathrm{z}$ olejem napędowym. Jednocześnie widać, że emisja tlenków azotu $\mathrm{NO}_{\mathrm{x}}$ pozostała na podobnym poziomie przy zastosowaniu paliw gazowych. Dobrze znanym faktem jest, że zmniejszenie gęstości paliwa powoduje obniżenie emisji $\mathrm{NO}_{\mathrm{x}}$ oraz wzrost emisji $\mathrm{HC}$ oraz CO. Z punktu widzenia redukcji emisji $\mathrm{NO}_{\mathrm{x}}$, zwiększenie szybkości wywiązywania się ciepła i wyższe ciśnienie w cylindrze są czynnikami szkodliwymi [19]. Z rysunku 2 widać, że maksymalne ciśnienie w cylindrze i szybkość wywiązywania się ciepła zmniejszają się z do- 
attributed to an improved fuel-air mixing by an increased premixed combustion.

\subsection{Emission Characteristics}

The addition of gaseous fuel to the pilot fuel increases the $\mathrm{HC}$ concentration in the exhaust gas. A sharp increase was observed in $\mathrm{HC}$ emission with $2 \%$ biogas addition to diesel fuel. However, through further addition of $2 \% \mathrm{H}_{2}$, there is a reduction in $\mathrm{HC}$ concentration, but this is still higher when compared to diesel fuel operation. These observations can be linked to the lower charge temperature and fuel mixing calorific value resulting in less combustion allowing small quantities of fuel to escape the combustion process [17].

Reducing the fuel density increases $\mathrm{CO}$ emission [1, 18]. In this study the density of blended fuel decreased because of the lower density of gaseous fuel compared to diesel fuel. However, it can be seen that the $\mathrm{NO}_{\mathrm{x}}$ emissions remained more or less constant with gaseous fuels addition. It is well known that reducing fuel density lowers $\mathrm{NO}_{x}$ emission but increases $\mathrm{HC}$ and $\mathrm{CO}$. From a $\mathrm{NO}_{\mathrm{x}}$ control perspective, increased rate of heat release and pressure are counter-productive effects [19]. From Fig. 2, it can be seen that the peak in-cylinder pressure and rate of heat release decreases with biogas addition and then increases with $\mathrm{H}_{2}$; a similar pattern is obtained with $\mathrm{NO}_{x}$ emission in Fig. 7.

\section{Conclusion}

The study of gaseous fuels such as biogas $\left(60 \% \mathrm{CH}_{4}\right.$ and $40 \% \mathrm{CO}_{2}$ ) and $\mathrm{H}_{2}$ duel fuelled with diesel can reduce the peak in-cylinder pressure but further addition of $\mathrm{H}_{2}$ increases the pressure compared to diesel fuel only. Deterioration in engine performance in terms of thermal efficiency was observed on the dual fuel mode. Nevertheless, improvements in particulate matter such as particulate size and number have been beneficial when using gaseous fuels like biogas and $\mathrm{H}_{2}$. A noticeable increase in emissions, specifically $\mathrm{HC}$ and $\mathrm{CO}$ was observed during the dual fuel mode. However, diesel-biogas fuelling shows small improvements in $\mathrm{NO}_{\mathrm{x}}$ compared to diesel fuel only. Dual-fuel combustion using biogas seems to be a promising way in controlling both smoke and particulate matter so that they can be eliminated easier by the after-treatment system. As an abundant source and renewable fuel, biogas gives an advantage in term of fuel-economy.

\section{Acknowledgements}

The Department of National Education of Republic of Indonesia is acknowledged for the provision of the $\mathrm{PhD}$ scholarship and maintenance grants to Mr. H.S. Tira.

Paper reviewed/Artykut recenzowany datkiem biogazu, a następnie zwiększają z dodatkiem H2. Podobny trend występuje dla $\mathrm{NO}_{\mathrm{x}}$ (rys. 7).

\section{Wnioski}

Badania paliw gazowych takich jak biogaz $\left(60 \% \mathrm{CH}_{4} \mathrm{i}\right.$ $40 \% \mathrm{CO}_{2}$ ) oraz wodór $\mathrm{H}_{2}$ dostarczanych w układzie podwójnego zasilania z olejem napędowym wykazały, że biogaz może obniżyć maksymalne ciśnienie w cylindrze, natomiast dalszy dodatek $\mathrm{H}_{2}$ powoduje wzrost ciśnienia w porównaniu z zasilaniem samym olejem napędowym. Przy podwójnym zasilaniu zaobserwowano ogólnie pogorszenie sprawności cieplnej silnika. Jednocześnie przy zastosowaniu paliw gazowych takich jak biogaz i $\mathrm{H}_{2}$ stwierdzono zmniejszenie emisji cząstek stałych zarówno pod względem liczbowym jak i wymiarowym oraz znaczący wzrost emisji niespalonych węglowodorów HC i tlenku węgla CO. Z kolei zasilanie olejem napędowym i biogazem spowodowało niewielkie zmniejszenie emisji tlenków azotu $\mathrm{NO}_{\mathrm{x}} \mathrm{w}$ porównaniu $\mathrm{z}$ zasilaniem samym olejem napędowym. Podwójne zasilanie silnika ZS z użyciem biogazu wydaje się być obiecującym sposobem ograniczania emisji cząstek stałych i zadymienia spalin. Jako paliwo odnawialne dostępne w znacznych ilościach, biogaz może być korzystnym rozwiązaniem dla gospodarek paliwowych wielu krajów.

\section{Podziękowania}

Autorzy wyrażają wdzięczność Ministerstwu Edukacji Narodowej Republiki Indonezji za zapewnienie stypendium doktoranckiego oraz stypendiów na koszty utrzymania dla p. H.S. Tira.

\section{Bibliography/Literatura}

[1] Nwafor O.M.I., Rice G.: Combustion characteristics and performance of natural gas in high speed indirect injection diesel engine. Renewable Energy, 1994. 5(Part II).

[2] Ganesan V.: Safety aspects for the use of hydrogen, in Summer school of hydrogen energy.1984 IIT Madras.

[3] Bedoya I.D., Arrieta A.A. Cadavid F.J.: Effects of mixing system and pilot fuel quality on diesel-biogas dual fuel engine performance. Bioresource Technology, 2009.100.

[4] Jawurek H.H., Lane N.W., Rallis C.J.: Biogas/petrol dual fuelling of SI engine for rural third world use. Biomass, 1990. 13.

[5] Porpatham E., Ramesh A., Nagalingam B.: Investigation on the effect of concentration of methane in biogas when used as a fuel for a spark ignition engine. Fuel, 2008. 87.

[6] Malenshek M., Olsen D.B.: Methane number testing of alternative gaseous fuels. Fuel 2009. 88.

[7] Bari S.: Effect of carbon dioxide on the performance of biogas/ diesel dual-fuel engine. In World Renewable Energy Congress, WREC, 1996.

[8] Henham A., Makkar M.K.: Combustion of simulated biogas in a dual-fuel diesel engine. Energy Conversion Management, 1998. 39(16-18). 
[9] Abu-Jrai A., Tsolakis A., Megaritis A.: The influence of $\mathrm{H}_{2}$ and $\mathrm{CO}$ on diesel engine combustion characteristics, exhaust gas emissions, and after treatment selective catalytic $\mathrm{NO}_{x}$ reduction. International. Journal of Hydrogen Energy, 2007. 32(15).

[10] Wyszynski M.L., MegaritisA., Karlovsky J., Yap D., Peucheret S., Lehrle R.S., Xu H., Golunski S.: Facilitation of HCCI combustion of biogas at moderate compression Ratios by application of fuel reforming and inlet air heating. Journal of KONES Internal Combustion Engines. 2004. 11(3-4).

[11] Karlovsky J., Wyszynski M.L.: Bio fuel for clean and efficient engines: enabling controlled autoignition (CAI) combustion technology by fuel reforming, in Carbon Trust Research, Development \& Demonstration Projects, Final Report, CT 2002-6-191. 2004, The University of Birmingham: Birmingham, UK. P. 34.

[12] Theinnoi K., Tsolakis A., Chuepeng S., York A.P.E., Cracknell R.F., Clark R.H.: Engine performance and emissions from the combustion of low-temperature Fischer-Tropsch synthetic diesel fuel and biodiesel rapeseed methyl ester blends. Int. Journal Vehicle Design, 2009. 50(Nos. 1/2/3/4).

[13] Verhelst S., Wallner T.: Hydrogen-fuelled internal combustion engines. Progress in Energy and Combustion Science, 2009. 35(6).

[14] Mustafi N.N., Raine R.R.: A study of the emissions of a dual fuel engine operating with alternative gaseous fuels. SAE Technical Paper Series, 2008. SAE 2008-01-1394.

Mr. Hendry Sakke Tira, MEng. - Master degree in mechanical engineering from Gadjah Mada University, Indonesia. PhD student at University of Birmingham, UK.

Mgr inż. Hendry Sakke Tira-absolwent Gadjah Mada University, Indonezja. Doktorant w Uniwersytecie Birmingham, Wielka Brytania.

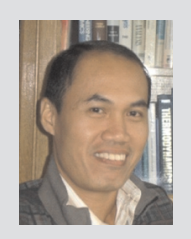

Mr. Simaranjit Singh Gill, MEng. - Master degree in mechanical engineering from University of Birmingham, UK. PhD student at University of Birmingham, UK. mgr inż. Simaranjit Singh Gill - absolwent (2009) $i$ obecnie doktorant $w$ Uniwersytecie Birmingham, Wielka Brytania.

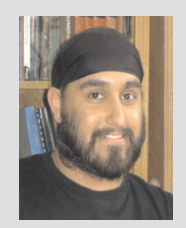

Mr. Kampanart Theinnoi, MEng., PhD. - PhD Birmingham University, King Mongkut's University of Technology North Bangkok, Thailand.

dr inż Kampanart Theinnoi-doktorat z Uniwersytetu Birmingham, King Mongkut's University of Technology North Bangkok, Tajlandia.

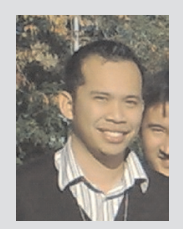

Mr. Joshua Shenker, MEng. - Master degree in mechanical engineering from University of Birmingham, UK. PhD student at University of Birmingham, UK. Mgr inż. Joshua Shenker-absolwent (2009) i obecnie doktorant $w$ Uniwersytecie Birmingham, Wielka Brytania.

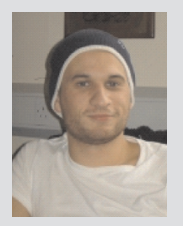

[15] Theinnoi K., Rounce P., Tsolakis A., Wyszynski M.L., Xu H.M., York A.P.E.: Activity of prototype on exhaust emissions from biodiesel fuelled engines. SAE Technical Paper Series, 2008. SAE 2008-01-2514.

[16] Sumlya S., Yokota H.: Diesel oxidation catalyst system for PM control. SAE Technical Paper Series, 2008. SAE 200828-0069.

[17] Papagiannakis R.G., Hountalas D.T.: Combustion and exhaust emission characteristics of a dual fuel compression ignition engine operated with pilot diesel fuel and natural gas. Energy conversion and management, 2004. 45(18-19).

[18] Sarvi A., Fogelholm C.J., Zevenhoven R.: Emissions from large-scale medium-speed diesel engines: 1 . Influence of engine operation mode and turbocharger. Fuel Processing Technology, 2008. 89(5).

[19] Sarvi A., Fogelholm C.J., Zevenhoven R.: Emissions from large-scale medium-speed diesel engine: 2 . Influence of fuel type and operating mode. Fuel Processing Technology, 2008, $89(5)$.

Mr. Miroslaw L. Wyszynski, MEng., PhD., MSAE, MSIMP, PTNSS - Professor in the Faculty of Mechanical Engineering at University of Birmingham, UK.

Prof. dr inż. Mirosław L. Wyszyński, - Profesor w na Wydziale Mechanicznym Uniwersytetu Birmingham, Wielka Brytania.

e-mail:M.L.Wyszynski@bham.ac.uk

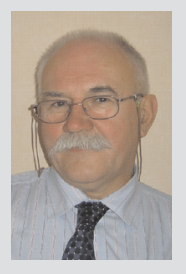

Mr. Athanasios Tsolakis, DEng., MIMechE - Senior lecturer in Automotive Engineering, School of Mechanical Engineering, University of Birmingham, UK.

$\mathrm{Dr}$ inż. Athanasios Tsolakis, MIMechE - starszy adiunkt inżynierii samochodowej, Wydziat Mechaniczny, Uniwersytet Birmingham, Wielka Brytania. e-mail:A.Tsolakis@bham.ac.uk

Mr. Chia S. Lau, BEng. - graduated from Nanyang Technological University, PhD student at University of Birmingham, UK.

Inż. Chia S Lau-absolwent Nanyang Technological University, Singapore (Beng Mech). Obecnie doktorant w Uniwersytecie Birmingham, Wielka Brytania.

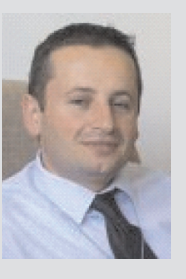

Mr. Karl Dearn, PhD, MEng, Wh SSch, Wh Sch, AMIMechE - Lecturer in Mechanical Engineering, University of Birmingham, UK.

Dr inż. Karl Dearn, Wh SSch, Wh Sch, AMIMechE, doktorat Birmingham adiunkt w Inżynierii Samochodowej, Uniwersytet Birmingham, Wielka Brytania.

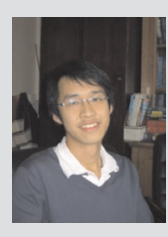

Mr. Dale Turner, MEng (PhD Viva Voce $1^{\text {st }}$ June 2010) - MEng University of Birmignham, currently Research Fellow, UK.

Mgrinż. Dale Turner, (obrona doktoratu 1 czerwca 2010) - absolwent Birmingham, pracowniknaukowo-badawczy

w Uniwersytecie Birmingham, Wielka Brytania.
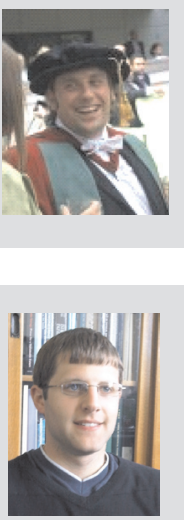